удк 616-006.

DOI 10.11603/2414-4533.2019.3.10553

(СБ. О. СУПРУНЕЦЬ, О. Л. СУПРУНЕЦЬ

Волинська обласна клінічна лікарня

\title{
Органозберігальні операції при диференційованій карциномі щитоподібної залози
}

Мета роботи: провести аналіз органозберігальних операцій у хворих із диференційованим раком для оптимізації об’єму операційного втручання.

Ключові слова: органозберігальні операції; карцинома; щитоподібна залоза.

Патологія щитоподібної залози з кожним роком привертає все більше уваги, оскільки, за даними МО3, з 2005 по 2011 р. її рівень зріс на 12 \% і дана тенденція продовжується.

Особливо хвилює проблема злоякісних новоутворень залози, яка стала актуальна після аварії на Чорнобильській АЕС. Так, із 1990 р. у країні зафіксовано збільшення рівня захворюваності на рак щитоподібної залози осіб до 18 років у $10-12$ разів, більшість із них понад 90 \% припадає на папілярну карциному [1, 3, 4, 5, 6].

За даними ВОО3, папілярною мікрокарциномою називають карциному розміром $\geq 10$ мм у діаметрі. Методика оперативного лікування є супереч- ливою. Загалом тактика лікування пацієнтів із папілярною карциномою достатньо агресивна і полягає в тотальній тиреоїдектомії з дисекцією лімфатичних колекторів [1] та інколи з подальшою абеляцією тиреоїдного залишку. Проте багато хірургів на сьогодні відстоюють можливість виконання органозберігальних операцій при папілярній карциномі, в якій відсутні ознаки виходу за межі органа [2]. Дискусійність щодо даного питання спостерігають також у тиреоїдних асоціаціях (табл.1).

Мета роботи: провести аналіз органозберігальних операцій у хворих із диференційованим раком для оптимізації об’єму операційного втручання.

Таблиця 1. Порівняння даних Американської та Європейської тиреоїдних асоціацій

\begin{tabular}{|c|c|c|}
\hline Показники & Американська тиреоїдна асоціація & Європейська тиреоїдна асоціація \\
\hline $\begin{array}{l}\text { Показання до } \\
\text { пункційної біопсії }\end{array}$ & Залежить від данних УЗД (TI-RADS) & $\begin{array}{l}\text { Вузол більше } 1 \text { см або менший, } \\
\text { але входить до групи ризику }\end{array}$ \\
\hline $\begin{array}{l}\text { Показання до } \\
\text { операційного втручання } \\
\text { при цитологічних даних } \\
\text { із підозрою на рак }\end{array}$ & $\begin{array}{l}\text { Є можливість спостереження без } \\
\text { операції при доведеному неагресивному } \\
\text { диференційованому раку щитоподібної залози }\end{array}$ & Показано операційне втручання \\
\hline $\begin{array}{l}\text { Показання до тотальної } \\
\text { тиреоїдектомії }\end{array}$ & $\begin{array}{l}\text { Гемітиреоїдектомія можлива при } \\
\text { неагресивному тиреоїдному раку } \\
\text { T1-2N0M0 }\end{array}$ & Для будь-якого раку ЩЗ \\
\hline $\begin{array}{l}\text { Показання до } \\
\text { застосування } \\
\text { радіоактивного йоду-131 }\end{array}$ & $\begin{array}{l}\text { Навіть при інтратиреоїдній пухлині менше } \\
4 \text { см або мікрометастазах папілярного раку } \\
\text { ЩЗ до центральної групи лімфатичних вузлів } \\
\text { можна утриматись від призначення радіо- } \\
\text { йодабляції }\end{array}$ & $\begin{array}{l}\text { Можна уникнути тільки в групі } \\
\text { дуже низького ризику - солітарна } \\
\text { інтратиреоїдна мікрокарцинома } \\
\text { без метастазів у пацієнтів старше } \\
18 \text { років }\end{array}$ \\
\hline $\begin{array}{l}\text { Критерії } \\
\text { післяопераційної } \\
\text { оцінки стану хвороби } \\
\text { пролікованих пацієнтів }\end{array}$ & $\begin{array}{l}\text { Визнає доцільним оцінювати критерії } \\
\text { одужання відповідно до вихідного статусу } \\
\text { (категорія ризику: низька, проміжна, висока) та } \\
\text { відгуку на лікування (відмінний, проміжний, } \\
\text { біохімічно неповний, структурно неповний), } \\
\text { а потім робити висновки щодо подальшого } \\
\text { моніторингу та необхідного додаткового } \\
\text { лікування; показники цільового рівня } \\
\text { тиреоглобуліну суттєво пом'якшені) }\end{array}$ & $\begin{array}{l}\text { Рекомендоване досягнення } \\
\text { нульового, базального та } \\
\text { стимульованого тиреоглобуліну } \\
\text { сироватки для визнання пацієнта } \\
\text { здоровим }\end{array}$ \\
\hline
\end{tabular}


В обстеженні брали участь 17 пацієнтів (16 жінок та один чоловік), віком від 23 до 62 років. Причиною органозберігальної операції в 11 випидках була відмова пацієнтів від тотальної тиреоїдектомію, в 4 - при невизначених цитологічних даних та у 2 хворих за результатами експрес-гістологічного дослідження встановити діагноз па- пілярна карцинома не вдалося. Аналіз проводили за даними історій хвороб та амбулаторних карток. Спостереження за пацієнтами проводили від 1,5 до 3 років пісялопераційного періоду, що відповідає загальноприйнятим даними літератури до виявлення істинних рецедивів. Результати доопераціного обстеження представлено в таблиці 2.

\section{Таблиця 2. Результати досліджень}

\begin{tabular}{||l|l||}
\hline \hline Пацієнти & Жінки, $\mathrm{n}=16$, чоловіки, $\mathrm{n}=1$ \\
\hline Середній вік, роки & 42,1 \\
\hline Тонкоголкова аспіраційна пункційна біопсія & Виконано 15 (у 4 невизначені цитологічні дані, не виконано 2 \\
\hline Експрес-гістологічне дослідження & 7 (у 2 підтвердити діагноз не вдалося) \\
\hline $\begin{array}{l}\text { Ультразвукове дослідження щитоподібної } \\
\text { залози, діаметр вузла до 1 см }\end{array}$ & 14 \\
\hline $\begin{array}{l}\text { Ультразвукове дослідження щитоподібної } \\
\text { залози, діаметр вузла 1-2 см }\end{array}$ & 3 \\
\hline
\end{tabular}

Аналіз органозберігальних операцій у пацієнтів із папілярною карциномою дозволив зробити висновки: протягом спостереження всім пацієнтам проводили повторні УЗД щитоподібної залози з лімфатичними колекторами. Метастатичні зміни в лімфатичних колекторах у пацієнтів обстежуваної групи не виявлено. У 2 пацієнтів у залишковій частці через 1,5 року та 1,7 року за результатами УЗД підтверджено вузлоутворення, після проведеної тонкоголкової аспіраційної пункційної біо-

\section{СПИСОК ЛІТЕРАТУРИ}

1. Reiners Ch. Radioiodine therapy in differentiated thyroid cancer: indications and procedures / Ch. Reiners // Best. Pract. Res. - 2008. - No. 6. - Vol. 22.

2. Болгов М. Ю. Віддалені результати органозберігаючих операцій при високодиференційованих карциномах щитоподібної залози // Ендокринологія. - 2009. - Т. 14, № 1. - С. 21 - 26.

3. Черенько С. М. Огляд нових (2015) клінічних рекомендацій американської тиреоїдної асоціації (АТА) щодо ведення дорослих пацієнтів з тиреоїдними вузлами та диференційованим раком щитовидної залози // Клінічна ендокринологія та ендокринна хірургія. - 2015. - № 4. - С. 80 - 88.

4. Тронько Н. Д. Рак щитовидной железы у детей Украины

\section{REFERENCES}

1. Reiners, C., Dietlein, M., \& Luster, M. (2008). Radioiodine therapy in differentiated thyroid cancer: indications and procedures. Best Practice \& Research Clinical Endocrinology \& Metabolism, 22 (6), 989-1007.

2. Bolhov, M.Yu. (2009). Viddaleni rezultaty orhanozberihaiuchykh operatsii pry vysokodyferentsiiovanykh kartsynomakh shchytopodibnoi zalozy [Long-term results of organ-preserving псії даних про онкологію не отримано. У групі пацієнтів із залишковою часткою на момент обстеження даних про вузлоутворення не отримали.

Проведені органозберігальні операції при диференційованому раку щитоподібної залози із низьким рівнем агресивності підтвердили актуальність. Для визначення можливості та доцільності застосування органозберігальних операцій при диференційованому раку необхідно продовжити спостереження для його поглибленого вивчення. (последствия Чернобыльской катастрофы) / Н. Д. Тронько, Т. И. Богданова. - К. : Чернобыльинтеринформ, 1997. - 200 с. 5. Pathology and genetics of tumours of endocrine organs. WHO classification of tumours / R. DeLelis, R. Lloyd, Ph. Heitz, Ch. Eng. - Lyon: IARC Press, 2004. - 320 p.

6. Rosai J. Tumors of the thyroid gland / J. Rosai, M. L. Cargangiu, R. A. Dellelis. - Washington, D.C.: Armed Forces Institute of Pathology, 1992. - 343 p.

7. Черенько С. М. Вузловий зоб і рак щитовидної залози: які підходи до дагностики і лікування рекомендує американська тиреоїдна асоціація в 2015p // Міжнародний ендокринологічний журнал. - 2016. - № 2. - С. 65 - 75. 
Thyroid Association (ATA) for the management of adult patients with thyroid nodes and differentiated thyroid cancer]. Klinichna endokrynolohiia ta endokrynna khirurhiia - Clinical Endocrinology and Endocrine Surgery, 4, 80-88 [in Ukrainian]. 4. Tronko, N.D., \& Bohdanova, T.I. (1997). Rak shhytovidnoy zhelezyy u detey Ukrainy (posledstviya Chernobyylskoy katastrofyy) [Thyroid cancer in children of Ukraine (consequences of the Chernobyl disaster)]. Kyiv: Chernobylinterinform [in Ukrainian]. 5. DeLelis, R., Lloyd, R., Heitz, Ph., \& Eng, Ch. (2004). Pathology and genetics of tumours of endocrine organs. WHO classification of tumours. Lyon: IARC Press.

6. Rosai, J., Cargangiu M.L., \& Dellelis R.A. (1992). Tumors of the thyroid gland. Washington, D.C.: Armed Forces Institute of Pathology.

7. Cherenko, S.M. (2016). Vuzlovyi zob i rak shchytovydnoi zalozy: iaki pidkhody do diahnostyky i likuvannia rekomenduie amerykanska tyreoidna asotsiatsiia v 2015r. [Nodular goiter and thyroid cancer: what approaches to diagnosis and treatment do the American Thyroid Association recommend in 2015]. Mizhnarodnyi endokrynolohichnyi zhurnal - International Journal of Endocrinology, 2, 65-75 [in Ukrainian].

Отримано 26.06.2019

Електронна адреса для листування: suprunetzbogdan@gmail.com

\author{
B. O. SUPRUNETS, O. L. SUPRUNETS
}

Volyn Regional Clinical Hospital

\title{
ORGAN-PRESERVING SURGERIES AT DIFFERENTIATED CARCINOMA OF THE THYROID GLAND
}

The aim of the work: to analyze organ-preserving surgeries in patients with differentiated cancer to optimize the volume of surgical intervention.

Key words: organ-preserving surgery; carcionoma; thyroid gland.

\author{
Б. О. СУПРУНЕЦ, О. Л. СУПРУНЕЦ
}

Волынская областная клиническая больница

\section{ОРГАНОСОХРАНЯЮЩИЕ ОПЕРАЦИИ ПРИ ДИФФЕРЕНЦИРОВАННОЙ КАРЦИНОМЕ ІЩТОВИДНОЙ ЖЕЛЕЗЫ}

\footnotetext{
Цель работы: провести анализ органосохраняющих операций у больных с дифференцированным раком для оптимизации объема операционного вмешательства.
}

Ключевые слова: органосохраняющие операции; карцинома; щитовидная железа. 